\title{
Article
}

\section{Calculation Skills: Acne Rosacea}

\author{
Nuttall, Dilyse
}

Available at http://clok.uclan.ac.uk/21231/

Nuttall, Dilyse ORCID: 0000-0002-0561-5229 (2016) Calculation Skills: Acne Rosacea. Nurse Prescribing, 14 (10). p. 483. ISSN 2052-2924

It is advisable to refer to the publisher's version if you intend to cite from the work.

10.12968/npre.2016.14.10.483

For more information about UCLan's research in this area go to

http://www.uclan.ac.uk/researchgroups/ and search for <name of research Group>.

For information about Research generally at UCLan please go to http://www.uclan.ac.uk/research/

All outputs in CLoK are protected by Intellectual Property Rights law, including Copyright law. Copyright, IPR and Moral Rights for the works on this site are retained by the individual authors and/or other copyright owners. Terms and conditions for use of this material are defined in the policies page.

\section{CLoK}

Central Lancashire online Knowledge www.clok.uclan.ac.uk

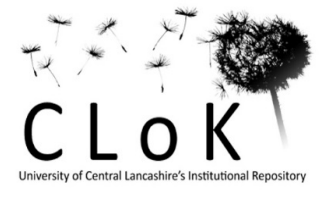




\section{Calculation Skills : Acne Rosacea}

NICE (2016) define acne rosacea as an inflammatory skin condition, which is chronic in nature. It can involve the forehead, eyes, nose, cheeks and chin. Signs and symptoms include thickened skin, telangiectasia, erythema, pustules, facial flushing, facial swelling and ocular rosacea (Culp \& Scheinfeld, 2009). Nice (2016) identify that there are five key types of acne rosacea:

- Papulopustular rosacea which presents as erythema to the centre of the face with papules and/or pustules

- Erythematotelangiectatic rosacea which presents as facial flushing, erythema to the centre of the face, with or without telangiectasia

- Ocular rosacea, presenting as inflammation of the eye and eyelid

- Granulomatous rosacea which presents as hard, uniform papules, red, yellow or brown in colour

- Phymatous rosacea characterised by irregular, thickened skin

Individuals can experience a number of types concurrently and with differing degrees of severity.

\section{Question 1}

Zoe has moderate papulopustular acne rosacea and is to be prescribed Mentronidazole $0.75 \%$ cream for topical application for 9 weeks. The treatment is available in amounts of $15 \mathrm{gram}, 30 \mathrm{gram}$ and 40 gram.

(i) How much mentronidazole (in $\mathrm{mg}$ ) will each available pack size contain?

(ii) Express the amount of metronidazole in each pack size in grams

\section{Question 2}

Andrew has severe papulopustular acne rosacea and requires oral oxytetracycline or tetracycline $500 \mathrm{mg}$ twice daily, for 8 weeks. Oxytetracycline is available as $250 \mathrm{mg}$ tablets in pack sizes of 28 tablets (f12.50). Tetracycline is available as $250 \mathrm{mg}$ tablets in a pack size of 28 tablets ( $\mathrm{f25.65).}$

(i) How many tablets will Andrew need for his course of treatment?

(ii) If oxytetracycline is chosen as the preferred treatment option, what would be the cost (assuming packs are not split) of the treatment?

(iii) What would the difference be in cost between using oxytetracycline and tetracycline for the 8 weeks?

\section{Question 3}


Yvonne also has severe papulopustular acne rosacea but prefers a once daily dose, so it is agreed that she will be prescribed Lymecycline $408 \mathrm{mg}$ once daily for 12 weeks. Lymecycline is available in pack sizes of $28408 \mathrm{mg}$ capsules (£9.18) and $56408 \mathrm{mg}$ capsules ( $\mathrm{f} 18.36$ )

What will be the cost of the course of treatment (using the available pack sizes most cost effectively)?

\section{Question 4}

Benjamin has mild renal impairment and is prescribed Doxycycline 100mg daily for 6 weeks for moderate papulopustular acne rosacea.

(i) How much Doxycycline (in grams) will he have taken in total on completion of the course of treatment?

(ii) If Benjamin's treatment was extended for a further 3 weeks, what percentage of his overall treatment would he have received in the first 6 weeks? Round your answer up or down to the nearest decimal point .

\section{$\underline{\text { Answers }}$}

\section{Question 1}

(i) Calculate $0.75 \%$ of $1 \mathrm{gram}$

$0.75 \div 100=0.0075 \mathrm{~g}$ per gram of cream

$0.0075 \times 1000=7.5 \mathrm{mg}$

$0.75 \%=7.5 \mathrm{mg}$ per gram

15 gram pack $=15 \times 7.5=112.5 \mathrm{mg}$

30 gram pack $=30 \times 7.5=225 \mathrm{mg}$

40 gram pack $=40 \times 7.5=300 \mathrm{mg}$

(ii) 15 gram pack $=112.5 \mathrm{mg}=0.1125 \mathrm{~g}$

30 gram pack $=225 \mathrm{mg}=0.225 \mathrm{~g}$

40 gram pack $=300 \mathrm{mg}=0.3 \mathrm{~g}$

\section{Question 2}

(i) Daily dose $=2 \times 250 \mathrm{mg}$ tablets twice per daily $=4$ tablets 
Course $=8$ weeks $=8 \times 7$ days $=56$ days

$56 \times 4=224$ tablets

(ii) 224 tablets $\div 28$ (pack size) $=8 \quad 8 \times £ 12.50=f 100$

(iii) Tetracycline $=8 \times £ 25.65=£ 205.20$ Oxyteracycline $=£ 100$ Difference $=205.20-100=$ f105.20

\section{Question 3}

No. capsules required $=12$ (weeks) $\times 7$ (days) $\times 1$ (capsule) $=84$

$3 \times 28=84 \quad 3 \times 9.18=£ 27.54$

$56+28=84 \quad 18.36+9.18=f 27.54$

Cost $=£ 27.54$

\section{Question 4}

(i) 6 (weeks) $\times 7$ (days) $\times 100(\mathrm{mg})=4200 \mathrm{mg}=4.2 \mathrm{~g}$

(ii) 9 (weeks) $=100 \%$

$1($ week $)=100 \div 9=11.1$

$6($ weeks $)=6 \times 11.1=66.6 \%$

\section{$\underline{\text { References }}$}

Culp, B. \& Scheinfeld, N. (2009) Rosacea - A Review, Pharmacy \& Therapeutics, 34(1): 38-45

NICE (2016) Clinical Knowledge Summaries: Rosacea - Acne, available at:

http://cks.nice.org.uk/rosacea-acne\#!scenario 